\title{
Side effects of the leukotriene receptor antagonists in asthmatic children
}

\author{
Demet Can*, Semiha Bahceci Erdem, Hikmet Tekin Nacaroglu, Canan Sule Unsal Karkiner, Ilker Gunay \\ From 3rd WAO International Scientific Conference (WISC) 2014 \\ Rio de Janeiro, Brazil. 6-9 December 2014
}

\section{Background}

Leukotriene receptor antagonists (LTRAs) are drugs which have been widely used more than ten years. As the use of LTRAs increases, our knowledge with respect to their side effects increases as well.

Objective: Our study was aimed to evaluate the observed side effects of LTRAs used in patients with astma.

\section{Methods}

1024 patients who were only treated with LTRAs owing to astma or early wheezing were included in the study for a five-year period. The observed side effects of LTRAs in these patients were retrospectively investigated. The side effects were divided into two parts as psychiatric and non- psychiatric.

\section{Results}

It was found out that $67.5 \%$ of $41(4 \%)$ patients in whom side effects were observed was male and their average age was 6.5. The rate of patients with asthma was $63.41 \%$ and it was $36.58 \%$ for patients with early wheezing. It was determined that sex, age and diagnosis (early wheezing or asthma) of the patients were ineffective in the emergence of side effects. The average period for the emergence of side effects was the fisrt month. It was observed that hyperactivity was the most frequently seen psychiatric side effect and abdominal pain was the nonpsychiatric side effect.

\section{Conclusions}

The side effects of LTRAs were common in children. Therefore, patients must be informed at the beginning of the treatment and they must be evaluated at certain intervals.

\footnotetext{
Behcet Uz Children Hospital, Turkey
}

(C) 2015 Can et al; licensee BioMed Central Ltd. This is an Open Access article distributed under the terms of the Creative Commons Attribution License (http://creativecommons.org/licenses/by/4.0), which permits unrestricted use, distribution, and reproduction in any medium, provided the original work is properly cited. The Creative Commons Public Domain Dedication waiver (http:// creativecommons.org/publicdomain/zero/1.0/) applies to the data made available in this article, unless otherwise stated.
doi:10.1186/1939-4551-8-S1-A6
Cite this article as: Can et al: Side effects of the leukotriene receptor antagonists in asthmatic children. World Allergy Organization Journal 2015 8(Suppl 1):A6.
Submit your next manuscript to BioMed Central and take full advantage of:

- Convenient online submission

- Thorough peer review

- No space constraints or color figure charges

- Immediate publication on acceptance

- Inclusion in PubMed, CAS, Scopus and Google Scholar

- Research which is freely available for redistribution

www.biomedcentral.com/submit

\section{Biomed Central}

Published: 8 April 2015 